Jurnal Santiaji Pendidikan, Volume 10, Nomor 2, Juli 2020 ISSN 2087-9016, e-ISSN 2685-4694

\title{
MODEL PEMBELAJARAN MASTERY LEARNING DENGAN STRATEGI TUTOR SEBAYA UNTUK MENINGKATKAN PRESTASI BELAJAR IPA
}

\author{
Ni Wayan Perthami \\ SMP Negeri 3 Banjarangkan \\ Email:Perthami@gmail.com
}

\begin{abstract}
ABSTRAK
Pembelajaran yang telah dilaksanakan selama ini lebih ke hal-hal yang Penelitian ini dilaksanakan di SMP Negeri 3 Banjarangkan. Penelitian ini bertujuan untuk meningkatkan prestasi belajar peserta didik. Perolehan data awal yang rendah pada siswa kelas IX DSMP Negeri 3 Banjarangkanpada semester I tahun pelajaran 2019/2020membuat peneliti mengupayakan membenahi proses yang kurang baik yang telah dilaksanakan. Perbaikan proses pembelajaran dilakukan melalui penerapa model pembelajaran mastery learning dengan strategi tutor sebaya. Model dan strategi ini diharapkan dapat memecahkan permasalahan yang sedang dihadapi. Setelah data dikumpulkan melalui instrumen tes prestasi belajar, diperoleh peningkatan hasil belajar dengan data awal yang ratarata kelasnya yaitu mencapai69,65 dengan prosentase ketuntasan belajar baru mencapai 38,46\%, pada siklus I meningkat menjadi75,92 rata-rata kelas dan 73,08\%untuk ketuntasan belajarnya. Sedangkan pada siklus II data tersebut telah meningkat menjadi 84,85rata-rata kelasnya dan $100 \%$ ketuntasan belajarnya. Data pada Siklus II ini sudah menunjukkan keberhasilan pelaksanaan pembelajaran yang melebihi indikator yang dipersyaratkan. Oleh karenanya peneliti berkesimpulan bahwa penerapan model pembelajaran mastery learning dengan strategi tutor sebaya dalam melaksanakan proses pembelajaran mampu meningkatkan prestasi belajar peserta didik.
\end{abstract}

Kata kunci: Model Pembelajaran Mastery Learning, Strategi Tutor Sebaya, dan Prestasi Belajar

\section{ABSTRACT}

The learning that has been done so far is more on the things conducted by this research in SMP Negeri 3 Banjarangkan. This study aims to improve student achievement. The low initial data acquisition in grade IX D students of SMP Negeri 3 Banjarangkan in the first semester of the academic year 2019/2020 made the researchers work on the unfavorable process that had been carried out. Improving the learning process is done through the adoption of a mastery learning learning model with peer tutoring strategies. This model and strategy are expected to solve the existing problem. After the data was collected through the learning achievement test instrument, an increase in learning outcomes was obtained with initial data reaching an average value of 69.65 with a percentage of mastery learning reaching $38.46 \%$, in the first cycle increasing to 75.92 grade average and 73,08\% for mastery learning. While in the second cycle the data increased to a class average of 84.85 and mastery learning 100\%. The data in Cycle II shows the success of learning that exceeds the required indicators. Therefore the researcher concludes that the application of the learning mastery learning model with peer tutoring strategy in implementing the learning process is able to improve student learning achievement. This improvement proves that the research carried out was successful.

Keywords: Mastery Learning Model Learning, Peer Tutor Strategy, and Learning Achievement

\section{PENDAHULUAN}

Perkembangan ilmu pengetahuan dan teknologi harus menjadi materi dasar dalam penyelenggaraan pendidikan agar generasi muda pengganti estafet kepemimpinan bangsa dapat bertahan dan berkembang membangun kepribadian diri dan kemajuan bangsa. Pendekatan belajar yang efektif dan efisien adalah belajar bersama. Belajar bersama yang diawali kegiatan struktur dapat dijadikan cara untuk mendorong perubahan sosial, 
Jurnal Santiaji Pendidikan, Volume 10, Nomor 2, Juli 2020 ISSN 2087-9016, e-ISSN 2685-4694

khususnya dalam rangka membangun pengelolaan sumber daya manusia dan alam yang berkelanjutan (Mulyana \& Agus, 2008)

Terdapat tiga sumbu atau disebutnya kuadran yang harus dipahami guru dalam mengembangkan seni mengajar, yaitu dipisahkannyadalam tiga dimensi dengan tiga kuadranberbeda.Tiapdimensiterdiriatas 3 (tiga) domain (ranah atau wilayah). Ranah Pertama menyangkut masalah Penyampaian(Delivery). Ranah Kedua menyangkutmasalah

Substansi(Substance).Ranah Ketiga menyangkutmasalah Situasi(Situation) (Sembiring, 2009)

Apa yang dipaparkan di depan adalah harapan-harapan yang mesti bisa dilakukan oleh guru. Namun, dalam pelaksanaan pembelajaran tidak semua harapan dapat dipenuhi karena guru masih terbiasa dengan cara pengajaran lama dan sulit untuk dirubah. Cara mengajar guru yang tetap berpola lama menyebabkan rendahnya prestasi belajar siswa. Nilai rata-rata peserta didik kelasIX D semester I masih di bawah KKM yaitu 69,65dengan ketuntasan belajar38,46\%. Hal tersebut menjadi fokus perhatian peneliti untuk melakukan perbaikan proses pembelajaran. Hal tersebut disebabkan oleh: 1) siswa belum paham dengan materi yang diajarkan oleh guru, 2) siswa masih lebih senang santai daripada belajar, 3) penyusunan materillmu Pengetahuan Alam (IPA)belum maksimal mengingatsiswa masih terbiasa menunggu. Dipihak guru kelemahannya adalah: 1) metode yang digunakan cenderung cemarah atau konvensional, 2) cara ngajar guru kurang menyenangkan, 3) guru kurang menguasai materi, 4) guru belum menghubungkan materi dengan kehidupan sehari-hari, 5) guru belum mampu secara tepat mengakomodasi kemampuan dan kebutuhan individual siswa.

Rendahnya prestasi belajar IPA siswa tersebut membuat peneliti selaku $\begin{array}{lll}\text { guru diSMP } & \text { Negeri }\end{array}$ Banjarangkanmengambil langkah dengan mengganti model pembelajaran menjadi model pembelajaranmastery lerarning dengan strategi tutor sebaya. Model pembelajaran mastery leraning memiliki ciri menurut Ahmadi (2005) berikut. 1) Siswa dapat belajar dengan baik dalam kondisi pengajaran yang tepat sesuai dengan harapanpengajar; 2) Bakat seorang siswa dalam bidang pengajaran dapat diramalkan, baik tingkatannya maupun waktu yang dibutuhkan untuk mempelajari bahan tersebut. Bakat berfungsi sebagai indeks tingkatan belajar siswa dan sebagai suatu ukuran satuan waktu; 3) Tingkat hasil belajar bergantung pada waktu yang digunakan secara nyata oleh siswa untuk mempelajari sesuatu dibandingkan dengan waktu yang dibutuhkan untuk mempelajarinya; 4) Tingkat belajar sama dengan ketentuan, kesempatan belajar bakat, kualitas pengajaran, dan kemampuan memahami pelajaran; 5) Setiap siswa memperoleh kesempatan belajar yang berdiferensiasi dan kualitas pengajaran yang berdiferensiasi pula.

Model ini dilaksanakan dengan strategi tutor sebaya yang dilaksanakan secara berkelompok, dimana tiap kelompok salah satu anggotanya menjadi tutor. Sehingga proses pembelajaran menjadi aktif dan tidak lagi pasif, karena pembelajaran berpusat pada siswa, guru disini hanya sebagai fasilitator saja.

Memperjelas arah penelitian dan memberikan gambaran secara kongkrit tentang permasalahan yang berhasil diidentifikasi serta upaya yang 
Jurnal Santiaji Pendidikan, Volume 10, Nomor 2, Juli 2020 ISSN 2087-9016, e-ISSN 2685-4694

direncanakan, maka rumusan masalah dalam penelitian ini adalah Apakah prestasi belajar IPA siswa dapat ditingkatkan dengan menerapkan model pembelajaran masterylearning dengan strategi tutor sebaya di kelasIX D Semester I Tahun Pelajaran 2019/2020 di SMP Negeri 3 Banjarangkan ?Rumusan masalah yang merupakan dasar dalam penyusunan kalimat tujuan. Setelah membuat rumusan masalah maka tujuan penelitian ini dapat dirumuskan untuk mengetahui seberapa tinggi peningkatan prestasi belajar IPA siswa akan terjadi setelah menggunakan model pembelajaran mastery learning dengan strategi tutor sebaya siswa kelas IX D semester I tahun pelajaran 2019/2020 di SMP Negeri 3 Banjarangkan.Pelaksanaan penelitian diupayakan agar dapat bermanfaat dalam pengembangan profesi keguruan. Dengan demikian manfaat penelitaian ini diharapkan dapat dirasakan bagi berbagai kalangan seperti: 1) Bagi siswa, penelitian dengan menerapkan pendekatan pembelajaran tematik dan belajar kelompok dapat meningkatkan prestasi belajar.

Bagiguru,hasilpenelitianinidapatdiperguna kansebagaialternatifsolusi penanggulangan permasalahan pembelajaran, dan secara serta merta mengindikasikan profesionalitas guru kelas dalam pengelolaan dan peningkatan kualitas pembelajaran. 3) Bagi sekolah, hasil penelitian dapat dipergunakan sebagai refrensi dalam menanggulangi permasalahan rendahnya output dan outcome pendidikan di sekolah ini.

Model pembelajaranmastery learning atau yang dalam bahasa Indonesianya disebut pembelajaran tuntas adalah salah satu usaha dalam pendidikan yang bertujuan untuk memotivasi peserta didik mencapai penguasaan (mastery level) terhadap kompetensi tertentu. Dengan menerapkan strategi pembelajaran tuntas dalam proses pembelajaran merupakan salah satu pendukung utama dalam pelaksanaan kurikulum berbasis kompetensi, berarti pembelajaran tuntas merupakan sesuatu yang harus dipahami dan dilaksanakan dengan sebaik-baiknya oleh seluruh warga sekolah secara tuntas, jika ada yang masih tertinggal maka guru harus melaksanakan suatu upaya pemberian perlakuan khusus untuk membantu anak tersebut mengejar ketertinggalannya dalam penguasaan materi atau suatu kompetensi. Dengan demikian semua anak baik yang pintar ataupun yang kurang dapat menguasai kompetensi yang dipersyaratkan dengan baik.

Perbedaan antara pembelajaran tuntas dengan pembelajaran konvensional adalah bahwa pembelajaran tuntas dilakukan melalui asas-asas ketuntasan belajar, sedangkan pembelajaran konvensional pada umumnya kurang memperhatikan ketuntasan belajar khususnya ketuntasan peserta didik secara individual.

Supaya pembelajaran tuntas dapat berlangsung secara terstruktur Winkel (dalam blog Murni) menyarankan sebagai berikut: a) Tujuan-tujuan pembelajaran yang harus dicapai ditetapkan secara tegas. Semua tujuan dirangkaikan dan materi pelajaran dibagi-bagi atas unit-unit pelajaran yang diurutkan, sesuai dengan rangkaian semua tujuan pembelajaran. b) Siswa dituntut supaya mencapai tujuan pembelajaran lebih dahulu, sebelum siswa diperbolehkan mempelajari unit pelajaran yang baru untuk mencapai tujuan pembelajaran. Jadi siswa dilarang untuk mempelajari pokok bahasan berikutnya 
Jurnal Santiaji Pendidikan, Volume 10, Nomor 2, Juli 2020 ISSN 2087-9016, e-ISSN 2685-4694

sebelum siswa tersebut mamahami pokok bahasan sebelumnya. c) Ditingkatkan motifasi belajar siswa dan efektivitas usaha belajar siswa, dengan memonitor proses belajar siswa melalui testing berkala dan kontinyu, serta memberikan umpan balik kepada siswa mengenai keberhasilan atau kegagalannya pada saat itu juga. d) Memberikan bantuan atau pertolongan kepada siswa yang masih mengalami kesulitan(Strategi Belajar Mengajar, 2020)

Sedangkan Ahmadi, Abu, dkk. (2005) yang dikutif dari blog Ahmad mengemukakan ada beberapa ciri belajar tuntas (mastery learning), yaitu:1)Siswa dapat belajar dengan baik dalam kondisi pengajaran yang tepat sesuai dengan harapanpengajar; 2) Bakat seorang siswa dalam bidang pengajaran dapat diramalkan, baik tingkatannya maupun waktu yang dibutuhkan untuk mempelajari bahan tersebut. Bakat berfungsi sebagai indeks tingkatan belajar siswa dan sebagai suatu ukuran satuan waktu; 3) Tingkat hasil belajar bergantung pada waktu yang digunakan secara nyata oleh siswa untuk mempelajari sesuatu dibandingkan dengan waktu yang dibutuhkan untuk mempelajarinya; 4) Tingkat belajar sama dengan ketentuan, kesempatan belajar bakat, kualitas pengajaran, dan kemampuan memahami pelajaran; 5) Setiap siswa memperoleh kesempatan belajar yang berdiferensiasi dan kualitas pengajaran yang berdiferensiasi pula. (http://pgmionemode.blogspot.com).

Prinsip-prinsip pengembangan pengajarannya menurut Sukmadinata, Nana Syaodih (2005) yang dikutif dari (http://pgmionemode.blogspot.com)

sebagai berikut: 1) Sebagian besar siswa dalam situasi dan kondisi belajar yang normal dapat menguasai sebagian terbesar bahan yang diajarkan. Tugas guru untuk merancang pengajarannya sedemikian rupa sehingga sebagian besar siswa dapat menguasai hampir seluruh bahan ajaran. 2) Guru menyusun strategi pengajaran tuntas mulai dengan merumuskan tujuan-tujuan khusus yang hendak dikuasai oleh siswa. 3) Sesuai dengan tujuan-tujuan khusus tersebut guru merinci bahan ajar menjadi satua-satuan bahan ajaran yang kecil yang medukung pencapaian sekelompok tujuan tersebut. 4) Selain disediakan bahan ajaran untuk kegiatan belajar utama, juga disusun bahan ajaranuntuk kegiatan perbaikan dan pengayaan. Konsep belajar tuntas sangat menekankan pentingnya peranan umpan balik.

Penilaianhasilbelajartidakmenggunakanac uannorma,tetapimenggunakanacuanpatoka n. 6) Konsep belajar tuntas juga memperhatikan adanya perbedaanperbedaan individual.

Dari uraian di atas jelas bahwa model pembelajaran tersebut berupaya semaksimal mungkin menyampaikan materi pelajaran dengan cara sebaikbaiknya sesuai dengan tuntutan pembelajaran dewasa ini agar tercapai ketuntasan secara individual. Cara inilah yang dapat digunakan sebagai dasar pemecahan masalah yang ada, mengingat pentingnya pemberian bantuan kepada siswa untuk memperoleh pengetahuan dan pemahamannya yang harus dikuasainya.

Para pengembang konsep belajar tuntas mendasarkan pengembangan pengajarannya pada prinsip-prinsip sebagai berikut: 1) Sebagian besar siswa dalam situasi dan kondisi belajar yang normal dapat menguasai sebagian terbesar bahan yang diajarkan. Tugas guru untuk merancang pengajarannya sedemikian rupa sehingga sebagian besar siswa dapat menguasai hampir seluruh bahan ajaran; 2) 
Jurnal Santiaji Pendidikan, Volume 10, Nomor 2, Juli 2020 ISSN 2087-9016, e-ISSN 2685-4694

Guru menyusun strategi pengajaran tuntas mulai dengan merumuskan tujuan-tujuan khusus yang hendak dikuasai oleh siswa;

3) Sesuai dengan tujuan-tujuan khusus tersebut guru merinci bahan ajar menjadi satua-satuan bahan ajaran yang kecil yang medukung pencapaian sekelompok tujuan tersebut; 4) Selain disediakan bahan ajaran untuk kegiatan belajar utama, juga disusun bahan ajaranuntuk kegiatan perbaikan dan pengayaan. Konsep belajar tuntas sangat menekankan pentingnya peranan umpan balik;

Penilaianhasilbelajartidakmenggunakanac uannorma,tetapimenggunakanacuapatokan ; 6) Konsep belajar tuntas juga memperhatikan adanya perbedaanperbedaan individual (dikutif dari http://pgmionemode.blogspot.combersumb er dari (Sukmadinata, Nana Syaodih, 2005).

Metode adalah cara atau teknik penyajian yang digunakan guru dalam membelajarkan materi/ pengetahuan kepada siswanya di sekolah. Metode adalah cara yang tersusun dan teratur untuk mencapaitujuan yang ditetapkan sebelumnya (Depdiknas, 2007)

Strategi pembelajaran dengan menggunakan tutor sebaya adalah suatu strategi pembelajaran yang memanfaatkan siswa lain yang memiliki kemampuan lebih tinggi untuk membantu temannya dalam menguasai materi pelajaran yang diajarkan. Siswa yang memiliki kemampuan lebih cepat menyerap materi pelajaran akan membantu siswa yang kurang cepat menyerap materi pelajaran.

Bahasa teman sebaya lebih mudah dipahami, selain itu dengan teman sebaya tidak ada rasa segan, rendah diri, malu, dan sebagainya sehingga diharapkan siswa yang kurang paham tidak segan-segan untuk mengungkapkan kesulitan-kesulitan yang dihadapi (Suherman, 2003). Diskusi kelompok terbimbing dengan model tutor sebaya merupakan kelompok diskusi yang beranggotakan 5-6 siswa pada setiap kelas di bawah bimbingan guru mata pelajaran dengan menggunakan tutor sebaya. Menurut Ischak dan warji dalam (Suherman, 2003) berpendapat bahwa "Tutor sebaya adalah sekelompok siswa yang telah tuntas terhadap bahan pelajaran, memberi bantuan kepada siswa yang mengalami kesulitan dalam memahami bahan pelajaran yang dipelajarinya". Mengingat bahwa siswa adalah unsur pokok dalam pengajaran yang pada akhirnya dapat mengubah tingkah lakunya sesuai dengan yang diharapkan.

Tutor sebaya merupakan salah satu model pembelajaran kooperatif. Menurut(Arends, 2018), pembelajaran yang menggunakan model kooperatif memiliki ciri-ciri sebagai berikut: siswa bekerja dalam kelompok secara kooperatif untuk menyelesaikan materi belajar, kelompok dibentuk dari siswa yang memiliki kemampuan tinggi, sedang dan rendah, jika mungkin, anggota kelompok berasal dari ras, budaya, suku, jenis kelamin yang berbeda-beda, penghargaan lebih berorientasi pada kelompok dari pada individu (Azizah, 2010)

Dengan memanfaatkan cara belajar seperti ini akan dapat membantu mempercepat transformasi pengetahuan yang disampaikan ke seluruh siswa dan dapat membuat siswa belajar lebih giat, lebih aktif, kreatif dan menyenangkan.

Metode pembelajaran tutor sebaya akan menghidupkan suasana yang kompetitif, sehingga setiap kelompok akan terus terpacu untuk menjadi kelompok yang terbaik. Oleh karena itu, selain aktivitas anggota kelompok, peran ketua kelompok atau tutor sangat besar 
Jurnal Santiaji Pendidikan, Volume 10, Nomor 2, Juli 2020 ISSN 2087-9016, e-ISSN 2685-4694

pengaruhnya terhadap keberhasilan kelompok dalam mempelajari materi ajar yang disajikan. Ketua kelompok dipilih secara demokratis oleh seluruh siswa. Misalnya, jika di suatu kelas terdapat 46 siswa, berarti ada 9 kelompok dengan catatan ada satu kelompok yang terdiri atas 6 siswa. Sebelum diskusi kelompok terbentuk, siswa perlu mengajukan calon tutor. Seorang tutor hendaknya memiliki kriteria: (1) memiliki kemampuan akademis di atas rata-rata siswa satu kelas; (2) mampu menjalin kerja sama dengan sesama siswa; (3) memiliki motivasi tinggi untuk meraih prestasi akademis yang baik; (4) memiliki sikap toleransi dan tenggang rasa dengan sesama; (5) memiliki motivasi tinggi untuk menjadikan kelompok diskusinya sebagai yang terbaik; (6) bersikap rendah hati, pemberani, dan bertanggung jawab; dan (7) suka membantu sesamanya yang mengalami kesulitan(Azizah, 2010: 19).

Menurut (Hamalik, 2005)tahaptahap persiapan dengan menggunakan pendekatan tutor sebaya adalah sebagai berikut: (1) Guru membuat program pengajaran satu pokok bahasan yang dirancang dalam bentuk penggalanpenggalan sub pokok bahasan. Setiap penggalan satu pertemuan yang didalamnya mencakup judul penggalan tujuan pembelajaran, khususnya petunjuk pelaksanaan tugas-tugas yang harus diselesaikan. (2) Menentukan beberapa orang siswa yang memenuhi kriteria sebagai tutor sebaya. Jumlah tutor sebaya yang di tunjuk disesuaikan dengan jumlah kelompok yang dibentuk. (3) Mengadakan latihan bagi para tutor. Dalam pelaksanaan tutorial atau bimbingan ini, siswa yang menjadi tutor bertindak sebagai guru. Sehingga latihan yang diadakan oleh guru merupakan semacam pendidikan guru atau siswa itu. Latihan di adakan dengan dua cara yaitu melalui latihan kelompok kecil dimana dalam hal ini yang mendapatkan latihan hanya siswa yang akan menjadi tutor, dan melalui latihan klasikal, dimana siswa seluruh kelas dilatih bagaimana proses pembimbingan ini berlangsung. (4) Pengelompokan siswa dalam kelompokkelompok kecil yang yang terdiri atas 4-6 orang. Kelompok ini disusun berdasarkan variasi tingkat kecerdasan siswa. Kemudian tutor sebaya yang telah ditunjuk di sebar pada masing-masing kelompok yang telah ditentukan (Sabaruddin, 2009)

Menurut Sagala (2003:216) dalam sebuah blog Hardymath menyatakan ada beberapa kelebihan dan kelemahan tutor sebaya secara berkelompok antara lain :

Adapun kelebihan tutor sebaya secara berkelompok anatara lain:1). Membiasakan siswa bekerja sama menurut paham demokrasi, memberikan kesempatan kepada mereka untuk mengembangkan sikap musyawarah dan bertanggung jawab.2) Membangkitkan kemauan belajar bersunguhsungguh.3)Guru tidak perlu mengawasi masing-masing murid secara individual, cukup hanya dengan memperhatikan kelompok saja atau tutor-tutor kelompoknya. Penjelasan tentang tugas pun dapat dilakukan hanya melalui tutor kelompoknya.4)Melatih tutor kelompok menjadi pemimpin yang bertanggung jawab dan membiasakan anggotaanggotanya untuk melaksanakan tugas kewajiban sebagai warga yang patuh pada peraturan.

Adapun kelemahan tutor sebaya secara berkelompok antara lain: 1) Segi penyusunan kelompok yakni a) Sulit untuk membuat kelompok yang homogen, baik intelegensi, bakat dan minat, atau daerah tempat tinggal. b) Murid-murid 
Jurnal Santiaji Pendidikan, Volume 10, Nomor 2, Juli 2020 ISSN 2087-9016, e-ISSN 2685-4694

yang oleh guru telah dianggap homogen, sering tidak cocok dengan anggota kelompoknya itu. c) Pengetahuan guru tentang pengelompokan itu kadang-kadang masih belum mencukupi. 2) Segi kerja kelompokyakni : a) Tutor kelompok kadang-kadang sukar untuk memberikan penertian kepada anggota, sulit untuk menjelaskan dan mengadakan pembagian kerja. b) Anggota kadang-kadang tidak mematuhi tugas-tugas yang diberikan oleh pemimpin kelompok. c) Dalam belajar bersama kadang-kadang tidak terkendali sehingga menyimpang dari rencana yang berlarut-

larut.(http://hardymath.blogspot.co.id)

Prestasi belajar di bidang
pendidikan adalah hasil dari pengukuran terhadap peserta didik yang meliputi faktor kognitif, afektif dan psikomotor setelah mengikuti proses pembelajaran yang diukur dengan menggunakan instrumen tes atau instrumen yang relevan. Melalui prestasi belajar ini dapat diketahui taraf penguasaan anak terhadap materi yang diberikan dalam proses belajar mengajar. Banyak definisi yang dikemukakan para ahli tentang prestasi belajar, dari berbagai sumber yang peneliti dapatkan akan disampaikan di antaranya.

Menurut (Bustalin, 2004)bahwa: "Prestasi adalah penilaian pendidikan tentang perkembangan dan kemajuan murid yang berkenaan dengan penguasaan bahan pelajaran yang disajikan kepada mereka dan nilai-nilai yang terdapat di dalam kurikulum. Belajar adalah perubahan tingkah laku untuk mencapai tujuan dari tidak tahu menjadi tahu dapat dikatakan sebagai proses yang menyebabkan terjadinya perubahan tingkah laku dan kecakapan seseorang. Sedangkan menurut Arif Gunarso (Sunarto, 2019)mengemukakan bahwa prestasi belajar adalah usaha maksimal yang dicapai oleh seseorang setelah melaksanakan usaha-usaha belajar. Prestasi dapat diukur melalui tes yang sering dikenal dengan tes prestasi belajar. Dan lagi menurut (Sunarto, 2019)bahwa hasil belajar dibedakan menjadi tiga aspek yaitu Kognitif, Afektif dan Psikomotor.

Dari pendapat para ahli diatas dapat disimpulkan bahwa prestasi belajar adalah perubahan tingkah laku mencakup tiga aspek (kognitif, afektif dan motorik) seperti penguasaan, penggunaan dan penilaian berbagai pengetahuan dan ketrampilan sebagai akibat atau hasil dari proses belajar dengan faktor-faktor yang mempengaruhinya yang tertuang dalam bentuk nilai yang di berikan oleh guru.

Dari beberapa pengertian belajar tersebut di atas, kata kunci dari belajar adalah perubahan perilaku. (Surya, 1997) mengemukakan ciri-ciri dari perubahan perilaku, yaitu: 1) Perubahan yang disadari dan disengaja (intensional); Perubahan perilaku yang terjadi merupakan usaha sadar dan disengaja dari individu yang bersangkutan. 2) Perubahan yang berkesinambungan (kontinyu); Bertambahnya pengetahuan atau keterampilan yang dimiliki pada dasarnya merupakan kelanjutan dari pengetahuan dan keterampilan yang telah diperoleh sebelumnya. 3) Perubahan yang fungsional; Setiap perubahan perilaku yang terjadi dapat dimanfaatkan untuk kepentingan hidup individu yang bersangkutan, baik untuk kepentingan masa sekarang maupun masa mendatang. 4) Perubahan yang bersifat positif; Perubahan perilaku yang terjadi bersifat normatif dan menunjukkan ke arah kemajuan. 5) Perubahan yang bersifat aktif; Untuk memperoleh perilaku yang baru, individu yang bersangkutan aktif 
Jurnal Santiaji Pendidikan, Volume 10, Nomor 2, Juli 2020 ISSN 2087-9016, e-ISSN 2685-4694

berupaya melakukan perubahan. 6) Perubahan yang bersifat permanen; Perubahan perilaku yang diperoleh dari proses belajar cenderung menetap dan menjadi bagian yang melekat dalam dirinya. 7) Perubahan yang bertujuan dan terarah; Individu melakukan kegiatan belajar pasti ada tujuan yang ingin dicapai, baik tujuan jangka pendek, jangka menengah maupun jangka panjang. 8) Perubahan perilaku secara keseluruhan; Perubahan perilaku belajar bukan hanya sekedar memperoleh pengetahuan semata, tetapi termasuk memperoleh pula perubahan dalam sikap dan keterampilannya.

\section{METODE PENELITIAN}

Agar lebih jelas mengenai lokasi penelitian ini maka peneliti menentukan SMP Negeri 3 Banjarangkan sebagai tempat penelitian. Sekolah ini terletak di Desa Nyalian Kecamatan Banjarangkan, Kabupaten Klungkung.Sebuah rancangan penelitian tidak bisa dianggap rendah. Arti sebuah rancangan sangat menentukan keberhasilan sebuah penelitian. Rancangan yang dipilih dalam penelitian ini adalah model rancangan (Arikunto, Suharsimi: Supardi, 2006).

Siswa di kelas IX DSMP Negeri 3 Banjarangkanyang berjumlah 26 orang siswa dijadikan subjek penelitian. Kelas tersebut diambil sebagai subjek penelitian karena rata-rata hasil belajar mereka belum sesuai dengan apa yang diharapkan. Siswa pada umumnya sulit memahami materi, kurang bersungguh-sungguh, sehingga berimbas pada hasil belajar yang rendah.Menurut (Arikunto, Suharsimi: Supardi, 2006)objek penelitian adalah sesuatu yang merupakan inti dari problematika penelitian. Dalam penelitian ini dinyatakan bahwa objek penelitiannya adalahpeningkatan prestasi belajar IPA siswa kelas IX Dsemester I tahun pelajaran 2019/2020 di SMP Negeri 3 Banjarangkan. Penelitian Tindakan Kelas yang akan dilaksanakan peneliti akan dilakukan sebanyak dua siklus. Untuk penelitian ini, akan berlangsung dari bulan Juli sampai bulan Nopember 2019.Untuk memperoleh data atau keteranganketerangan dalam kegiatan sesuai yang diinginkan, perlu dilakukan kegiatan observasi. Observasi atau teknik pengumpulan data yang digunakan dalam penelitian tindakan kelas ini menggunakan observasi dan tes prestasi belajar.Hasil akhir dari pelaksanaan penelitian akan diketahui berdasarkan pengkajian terhadap data yang didapatkan. Dalam penelitian ini pengkajian atau dianalisis dilakukan secara deskriptif, disajikan beruparata-rata, modus, median, dan presentase, serta pembandingan dengan indikator keberhasilan penelitian, juga dilakukan penyajian data dengan menyusun tabel dan grafik.

\section{HASIL PENELITIAN DAN PEMBAHASAN}

Kegiatan awal diperoleh hasil dari 26 siswa kelas IX D semester I tahun pelajaran 2019/2020SMP Negeri 3 Banjarangkan hanya 6 siswa $(23,08 \%)$ memperoleh nilai di atas KKM, 4 siswa $(15,38 \%)$ memperoleh nilai sama dengan KKM sedangkan yang lainnya yang jumlahnya 16 siswa $(61,54 \%)$ memperoleh nilai di bawah KKM. Data tersebut menunjukkan rendahnya prestasi belajar IPA. Berdasarkan data tersebut akhirnya peneliti memilih model para ahli untuk digunakan pada siklus selanjutnya.

Pada siklus I hasil pembahasan sebagai berikut: 
Jurnal Santiaji Pendidikan, Volume 10, Nomor 2, Juli 2020 ISSN 2087-9016, e-ISSN 2685-4694

1. Rata-rata (mean). Rumus berikut digunakan untuk mencari rata-rata kelas yaitu: $\frac{\text { Jumla hnilai }}{\text { Jumla hsiswa }}=\frac{1.974}{26}=75,92$

2. Median (titik tengah) :Jalan untuk menghitung median dilakukan dengan mengurut data/nilai siswa dari yang terkecil sampai terbesar. Setelah diurut apabila jumlah data ganjil maka mediannya adalah data yang ditengah. Kalau jumlahnya genap maka dua data yang di tengah dijumlahkan dibagi 2 (dua). Untuk median yang diperoleh dari data siklus II dengan menggunakan cara tersebut adalah 76,00 .

3. Modus (angka yang paling banyak/paling sering muncul). Mencari modus dari sebuah data hasil penelitian merupakan sangat dalam sebuah analisis kuantitatif. Setelah data diaccending ternyata angka yang diperoleh yang merupakan angka atau nilai yang terbanyak muncul adalah 76,00 . Inilah modus yang diperoleh.

4. Untuk persiapan penyajian dalam bentuk grafik maka hal-hal berikut dihitung terlebih dahulu.

Banyak kelas $(\mathrm{K})=1+3,3 \times \log (\mathrm{N})$

$$
\begin{aligned}
& =1+3,3 \times \log 26 \\
& =1+3,3 \times 1,41 \\
& =1+4,65=5,65 \rightarrow 6
\end{aligned}
$$

Rentang kelas (r) = skor maks-skor min

$$
\begin{aligned}
& =82-65 \\
& =17
\end{aligned}
$$

\begin{tabular}{|c|c|c|c|c|}
\hline $\begin{array}{l}\text { No } \\
\text { Urut }\end{array}$ & Interval & $\begin{array}{c}\text { Nilai } \\
\text { Tengah }\end{array}$ & $\begin{array}{c}\text { Frekuensi } \\
\text { Absolut }\end{array}$ & $\begin{array}{c}\text { Frekuensi } \\
\text { Relatif }\end{array}$ \\
\hline 1 & $65-67$ & 66 & 1 & 3,85 \\
\hline 2 & $68-70$ & 69 & 3 & 11,54 \\
\hline 3 & $71-73$ & 72 & 0 & 0,00 \\
\hline 4 & $74-76$ & 75 & 13 & 50,00 \\
\hline 5 & $77-79$ & 78 & 6 & 23,08 \\
\hline 6 & $80-82$ & 81 & 3 & 11,54 \\
\hline & Total & & 26 & 100 \\
\hline
\end{tabular}

Panjang kelas interval (i) $=\frac{r}{K}=\frac{17}{6}=2,83$

Tabel 1. Data Kelas Interval Siklus I

Penyajian dalam bentuk grafik/histogram 


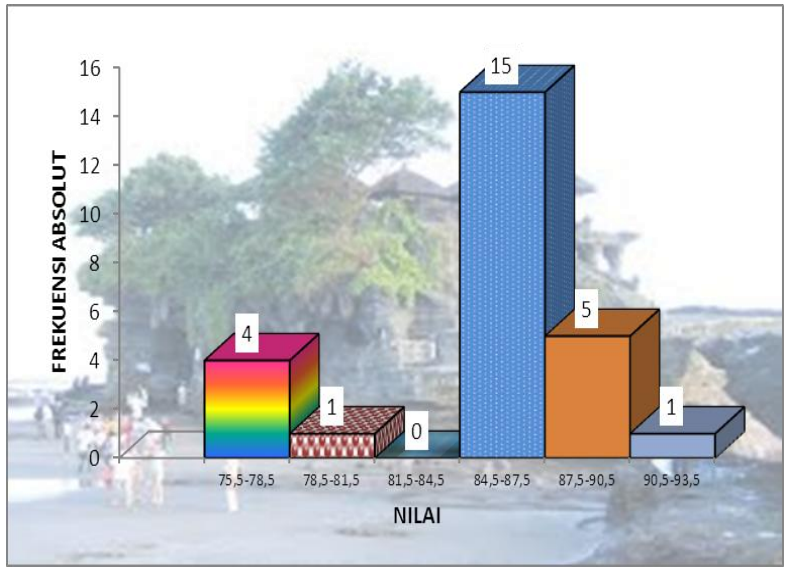

Gambar2. Histogram Siklus II

\section{SIMPULAN DAN SARAN}

Model pembelajaran mastery learning dengan strategi tutor sebaya dalam proses pembelajaran mampu membuat pembelajaran menjadi bermakna, mampu menuntaskanprestasi belajar siswa dapat memahami pembelajaran dengan lebih baik materi yang disampaikan. Semua fakta di atas dapat dibuktikan dengan data: Kegiatan awal nilai rata-rata baru mencapai 69,65 dengan ketuntasan belajar 38,46\%; Siklus I mengalami peningkatan menjadi 75,92 dengan ketuntasan belajar 73,08\%; Siklus II prestasi belajar IPA meningkat menjadi 84,85 dengan ketuntasan belajar 100\%.Jadi dapat disimpulkan bahwa model pembelajaran mastery learning dengan strategi tutor sebaya dapat meningkatkan prestasi belajar IPA siswa kelas IX D semester I tahun pelajaran 2019/2020di SMP Negeri 3 Banjarangkan.

Bukti keberhasilan penelitian yang telah disampaikan menjadi pedoman peneliti untuk menyampaikan saran sebagai berikut: 1) Bagi guru, disarankan menggunakan strategi yang sesuai dengan materi yang akan diajarkan dan melakukan analisis materi pelajaran yang akan disampaikan serta berperan dalam mendampingi siswa ketika proses pembelajaran berlangsung. 2) Bagi peneliti, untuk penelitian selanjutnya disarankan melakukan penelitian-penelitian yang berikutnya dengan lingkup mata pelajaran dan materi-materi pelajaran yang lebih luas lagi. 3) Siswa diharapkan mampu berperan aktif dalam kegiatan pembelajaran. Dengan terlibat aktif dalam pembelajaran tentu akan meningkatkan hasil belajarnya, selain pada penilaian kognitif tetapi juga pada penilaian afektif.

\section{DAFTAR PUSTAKA}

Arends, R. I. (2018). Learning to Teach. McGraw-Hill.

Arikunto, Suharsimi: Supardi, S. (2006). Penelitian Tindakan Kelas.

Azizah, R. (2010). Pengaruh Model Pembelajaran Tutor Sebaya Terhadap Hasil Belajar Matematika. Jurusan Pendidikan Matematika Fakultas Ilmu Tarbiyah Dan Keguruan Universitas Islam Negeri Syarif Hidayatullah Jakarta.

Bustalin. (2004). Prestasi Belajar dalam Pengajaran Remedial pada Mata Pelajaran IPS Ekonomi Kelas II Semester 1 SLTP Negeri 1 Linggang Bingung Kabupaten Kutai Barat. http:/artikel.us/html.

Depdiknas. (2007). Peraturan Menteri Pendidikan Nasional No. 41 Tahun 2007 Tanggal 23 November 2007.

Hamalik, O. (2005). Kurikulum dan Pembelajaran. Jakarta: PT. Bumi Aksara.

https://idiscover.lib.cam.ac.uk/primoexplore/search?query=any,contains, $\mathrm{M}$ cKay, P. (2006). Assessing Young Language Learners. Cambridge: Cambridge University Press.\&tab=cam_lib_coll\&search_sc ope $=$ SCOP_CAM_ALL\&vid $=44 C A$ M_PROD\&offset $=0$

Mulyana, \& Agus. (2008). Belajar Sambil Mengajar: Menghadapi Perubahan Sosial untuk Pengelolaan Sumberdaya Alam. Penerbit: Center for International Forestry Research (CIFOR) Dicetak oleh Penebar Swadaya. Jakarta.

Sabaruddin. (2009). Skripsi. Peranan Metode Tutor Sebaya Dalam Meningkatkan Hasil Belajar Siswa Kelas 5 SDN Inpres Karawa Kab. 
Jurnal Santiaji Pendidikan, Volume 10, Nomor 2, Juli 2020 ISSN 2087-9016, e-ISSN 2685-4694

Pinrang Pada Pokok Bahasan KPK dan FPB. Fakultas Ilmu Pendidikan Universitas Negeri Makassar.

Sembiring, M. G. (2009). The Art of Great Teaching Series. Mengungkap Rahasia dan Tips Manjur Menjadi Guru Sejati. Perpustakaan Nasional RI Katalog Dalam Terbitan. Best Publisher. Yogyakarta.

Strategi Belajar Mengajar. (2020). http://murniuni.blogspot.com/2010/10/strategibelajar-mengajar-pembelajaran.html

Suherman, E. (2003). Strategi Pembelajaran Matematika Kontemporer. Bandung: UPI.

Sunarto. (2019). Pengertian Prestasi Belajar. Book. http://sunartombs.wordpress.com/200 9/01/05/pengertian-prestasi-belajar/

Surya, M. (1997). Dalam Proses Belajar Mengajar. Bandung: PT Remaja Rosda Karya.

http://akhmadsudrajat.wordpress.com/200 9/11/02/pembelajaran-tuntasmastery-learning-dalam-ktsp/ http://hardymath.blogspot.co.id/2019/03/p ola-belajar-tutor-sebaya.html http://mumi-uni.blogspot.com/2010/10/strategibelajar-mengajar-pembelajaran.html 